\title{
BEHAVIOR OF RR SOYBEANS SUbJECTED TO DIFFERENT Formulations and Rates of Glyphosate in the REPRODUCtive PERIOD $^{1}$
}

\author{
Comportamento da Soja RR Submetida à Aplicação de Diferentes Formulações e Doses de \\ Glyphosate no Período Reprodutivo
}
ALBRECHT, A.J.P. ${ }^{2}$, ALBRECHT, L.P. ${ }^{3}$, KRENCHINSKI, F.H. ${ }^{3}$, PLACIDO, H.F. ${ }^{3}$, LORENZETTI, J.B. ${ }^{3}$, VICTORIA FILHO, R. $^{4}$, and BARROSO, A.A.M. ${ }^{5}$

\begin{abstract}
Recent studies indicate that glyphosate applied in post-emergence in RR soybean can eventually cause phytotoxic effects. However, there are many questions that need to be clarified in the scientific and technical contexts, involving the issue of RR soybeans regarding the use of glyphosate. This study has assessed the impact of the application of different doses and formulations of glyphosate in the reproductive period of RR soybean (R1 stage). For that purpose, an experiment in the field was conducted in two harvests $(2011 / 12$ and 2012/13), in which a 2 x 5 factorial design was used (formulations versus doses) totaling 10 treatments. In these two experiments the variables related to agronomic performance were: phytotoxicity (7, 14, 21 and 28 days after application), plant height, number of pods per plant, yield and weight of 100 grains (end of soy cycle). The results obtained allowed characterizing phytotoxicity and damages to the height and yield in RR soybean, with increasing rates of glyphosate applied in the reproductive period.
\end{abstract}

Keywords: Glycine max, herbicide, transgenic crops, phytotoxicity.

RESUMO - Resultados de pesquisas recentes indicam que o glyphosate aplicado em pósemergência na soja RR pode, em algumas situações, gerar efeitos fitotóxicos. Entretanto, persistem muitas dúvidas que precisam ser melhor elucidadas no âmbito científico e técnico, envolvendo a questão da soja transgênica (RR), sobre aplicação de glyphosate. Desse modo, o presente trabalho teve por objetivo avaliar o impacto da aplicação de diferentes doses e formulações de glyphosate, no periodo reprodutivo da soja RR (estádio R1). Para isso, foi conduzido um experimento no campo, por duas safras (2011/ 12 e 2012/13), em que foi utilizado arranjo fatorial $2 \times 5$ (formulações $x$ doses), totalizando 10 tratamentos. Nesses dois experimentos, as variáveis relacionadas ao desempenho agronômico foram: fitointoxicação (7, 14, 21 e 28 dias após a aplicação), altura de plantas, número de vagens por planta, produtividade e massa de 100 grãos (final do ciclo da cultura). Os resultados alcançados caracterizaram progressiva fitointoxicação e danos à altura e produtividade da soja $R R$, com o incremento das doses de glyphosate aplicadas no periodo reprodutivo.

Palavras-chave: Glycine max, herbicida, culturas transgênicas, fitotoxicidade.

Recebido para publicação em 20.11.2013 e aprovado em 2.6.2014.

2 USP/ESALQ, Piracicaba-SP, Brasil, <ajpalbrecht@yahoo.com.br>; ${ }^{3}$ UFPR Palotina-PR, Brasil; ${ }^{4}$ USP/ESALQ, Piracicaba-SP, Brasil; ${ }^{5}$ UNESP, Jaboticabal-SP, Brasil. 


\section{INTRODUCTION}

The importance of glyphosate is relevant in national and world markets of agricultural pesticides, thus highlighting the significance of this product and its intensive use. Products containing glyphosate are registered in more than 130 countries. In the world there are over marketed 150 brands containing glyphosate; its control is proven to over 300 weed species, and this herbicide is used in over 100 crops, with registration (Velini et al., 2009; Monsanto, 2012).

After the expansion in the use of this herbicide, tillage had significant progress in Brazil, having solidified over the years; another revolution in Brazilian and world agriculture has been provided by this molecule, now related to RR crops. In Brazil, in the last harvest (2012/ 2013), according to CONAB (National supply company) (2013), a crop area with soy was of 27.65 million hectares, being about 10\% higher than the previous crop, and RR (Roundup Ready) soybean crops account for almost $90 \%$ of the total area of soybean, or 24.45 million hectares (CÉLERES, 2013).

But even with undeniable success and acceptance of this technology, there are consistent reports that some soybean cultivars, even tolerant, can still present herbicide symptoms after application of glyphosate (Albrecht et al., 2013). These physiological responses may vary according to location, soil class, environmental conditions and other factors (Zablotowicz \& Reddy, 2004).

Results of recent surveys report that glyphosate can influence the nutritional balance, generate phytotoxic effects, affect the efficiency of water use, photosynthesis, accumulation of biomass, quality of seeds and grains produced, and thus the agronomic performance of the culture (Zablotowicz \& Reddy, 2007; Zobiole et al., 2010a,b,c; Albrecht \& Ávila, 2010; Albrecht et al., 2011a,b, Albrecht et al., 2012a,b; Cavaliere et al., 2012).

These results denote the possibility of compromising the agronomic performance of soybean under the application of glyphosate in postemergence. In this context, results in the current literature also demonstrate the possibility of any significant deleterious effects of glyphosate on RR soybeans in situations where application occurs outside the ideal time, namely, when it is performed, for example, in the early reproductive stage (Albrecht et al., 2011b).

However, the literature to this area requires further information concerning the application of this product at flowering, simulating situations that occur sporadically in the field, in which the producer loses the recommended point of application, or chooses to make a later application to control remaining weeds. Consequently, with this late stage of the application, its effects on the culture may be different from those observed at the optimum time of application. The objective of this study was to assess the behavior of RR soybeans subjected to application of increasing doses of glyphosate in two formulations, at the beginning of the reproductive period of culture.

\section{MATERIALS AND METHODS}

The experiment was conducted during two crops (2011/12 and 2012/13), in the production area in Palotina, located in the western region of the Brazilian state of Paraná, with the following coordinates: latitude $24^{\circ} 25^{\prime} 67^{\prime}$, south and longitude $53^{\circ} 82^{\prime}$ 57' $7^{\prime}$ west. The cultivar used was NK 7059 RR, with features such as: early maturing (maturity group 5.9), indeterminate growth habit and recommended population next to 300 plants ha ${ }^{-1}$ for the region worked. This was chosen because it has the largest area planted in crops 2009/10, 2010/ 11 and 2011/12, in the state of Paraná (Cocamar, 2012).

According to Köppen classification, the predominant climate type in the region is $\mathrm{Cfa}$ - mesothermal humid subtropical. The altitude of the area is $320 \mathrm{~m}$, and the soil was classified as typical Eutrustox Rhodic Hapludox. Chemical and physical soil analysis was done before the installation of the first crop of the experiment, at the depth of $0.0-0.20 \mathrm{~m}$. It presented the following results: $\mathrm{pH}$ $\left(\mathrm{CaCl}_{2}\right)=5.3 ; \mathrm{Al}=0.0 \mathrm{cmol}_{\mathrm{c}} \mathrm{dm}^{-3} ; \mathrm{H}+\mathrm{Al}=$ $6.01 \mathrm{cmol}_{\mathrm{c}} \mathrm{dm}^{3} ; \mathrm{C}=15.71 \mathrm{~g} \mathrm{dm}^{-3} ; \mathrm{P}$ (Mehlich) $=4.10 \mathrm{mg} \mathrm{dm}^{-3} ; \mathrm{K}=0.62 \mathrm{cmol}_{\mathrm{c}} \mathrm{dm}^{-3} ; \mathrm{Ca}=$ $6.06 \mathrm{cmol}_{\mathrm{c}} \mathrm{dm}^{-3} ; \mathrm{Mg}=2.06 \mathrm{cmol}_{\mathrm{c}} \mathrm{dm}^{-3} ; \mathrm{S}=$ $7.47 \mathrm{mg} \mathrm{dm}^{-3} ; \mathrm{CTC}=14.75 \mathrm{cmol}_{\mathrm{c}} \mathrm{dm}^{-3}$; and 
$\mathrm{V}=59.25 \%$. The clay, sand and silt total content were 64, 22 and 14\%, respectively.

Treatments were arranged in a $2 \times 5$ factorial (formulations $\mathrm{x}$ doses), in which were used two different glyphosate formulations: one presents in its composition the isopropylamine salt (Roundup Ready), and the other, the potassium salt (Zapp IQ), which were chosen for being distinct and present commercial products registered for postemergence application in RR soybean. The five doses were: $0.0,720,1440,2160$, and 2880 g e.a. ha${ }^{1}$ (for both formulations).

The application of the treatments was done at R1 development stage (Fehr et al., 1971). In it was used a backpack sprayer propelled at $\mathrm{CO}_{2}$ with a constant pressure of 2 bar (or 29 PSI), a flow rate of $0.65 \mathrm{~L} \mathrm{~min}^{-1}$, equipped with a bar with six nozzles range from the TeeJet series XR 11002 type, which, working a height of $50 \mathrm{~cm}$ from the target and a speed of $1 \mathrm{~m} \mathrm{~second}^{-1}$ in an applied range of $50 \mathrm{~cm}$ wide, provided a spray volume of $200 \mathrm{~L} \mathrm{ha}^{-1}$.

The dates and environmental conditions at the time of application of the treatments were: $\operatorname{crop} 2011 / 12$, day $11 / 14 / 2011$ (UR = $63 \%$; vv $\left.=4 \mathrm{~km} \mathrm{~h}^{-1} ; \mathrm{T}=27^{\circ} \mathrm{C}\right)$; and crop 2012/ 13 , day $11 / 16 / 2012$ (UR $=57 \%$; vv $=3 \mathrm{~km} \mathrm{~h}^{-1}$; $\mathrm{T}=29^{\circ} \mathrm{C}$ ). The data of rainfall and maximum and minimum temperatures for the period of duration of the experiment, in two crops, was collected daily and Figures 1 and 2 were prepared with this information.

Sowing and harvesting dates for the two crops corresponded to: crop 2011/12, sowing on $09 / 22 / 2011$ and harvest on $01 / 23 / 2012$; and crop 2012/13 on 09/17/2012 and 01/24/ 2013, respectively. The plots consisted of six rows five meters long (spacing $0.45 \mathrm{~m}$ between lines). For the assessments was used a floor area of $5.4 \mathrm{~m}^{2}$, in which were considered only the four central rows, discarding $1 \mathrm{~m}$ from each end of the rows (borders).

The use of fertilization techniques, installation of crop and phytosanitary management followed the requirements of Embrapa (Brazilian Enterprise of Agricultural Research) (2011). The experimental plots were kept free of weed presence throughout their development through hand hoeing.
Phytotoxicity was assessed at 7, 14, 21 and 28 days after application (DAA), by means of visual assessments, in which percentage scores were assigned to each experimental unit ( 0 for no injury and $100 \%$ for plant death) considering visible symptoms on plants, according to their development (SBCPD, 1995). The assessed variables related to agronomic performance were: plant height, number of pods per plant, yield and weight of 100 grains. The group of plants was also assessed, only to make sure that it did not differ among treatments.

To determine the height of the plants, 10 plants were assessed, randomly chosen from the area of the plots, by performing measurements with the aid of a millimeter ruler, considering the length of the base of the plant until the final pod insertion, and the results expressed in centimeters; as for the number of pods per plant, it was assessed by manually counting the number of pods, also in 10 plants. Both assessments were held during the full maturity (stage R8).

Plants were harvested by hand at the R8 stage, i.e., when $95 \%$ of the pods showed the typical staining of mature pods (Fehr et al., 1971). Then the pods were shelled in threshing for experiments, cleaned with the aid of screens and packed in paper bags.

Starting from the grain yield in the plots, was estimated the yield in $\mathrm{kg} \mathrm{ha}^{-1}$, for each treatment and repetition. Then, the mass of 100 grains was determined by weighing eight sub-samples for each field repetition. To calculate the yield and weight of 100 grains, the moisture content was adjusted to $13 \%$ wet basis.

The experimental design was in randomized blocks with four replications. Data from each harvest was analyzed separately, according to Pimentel-Gomes \& Garcia (2002), in which the data set of the factorial experiment of each crop was subjected to analysis of variance; when the $F$ values were significant $(P<0.05)$, t test and regression analysis was applied. The basic assumptions of the analysis of variance were verified; it was necessary to use transformation of the data only for the assessments of phytotoxicity. When choosing the best regression model, the 


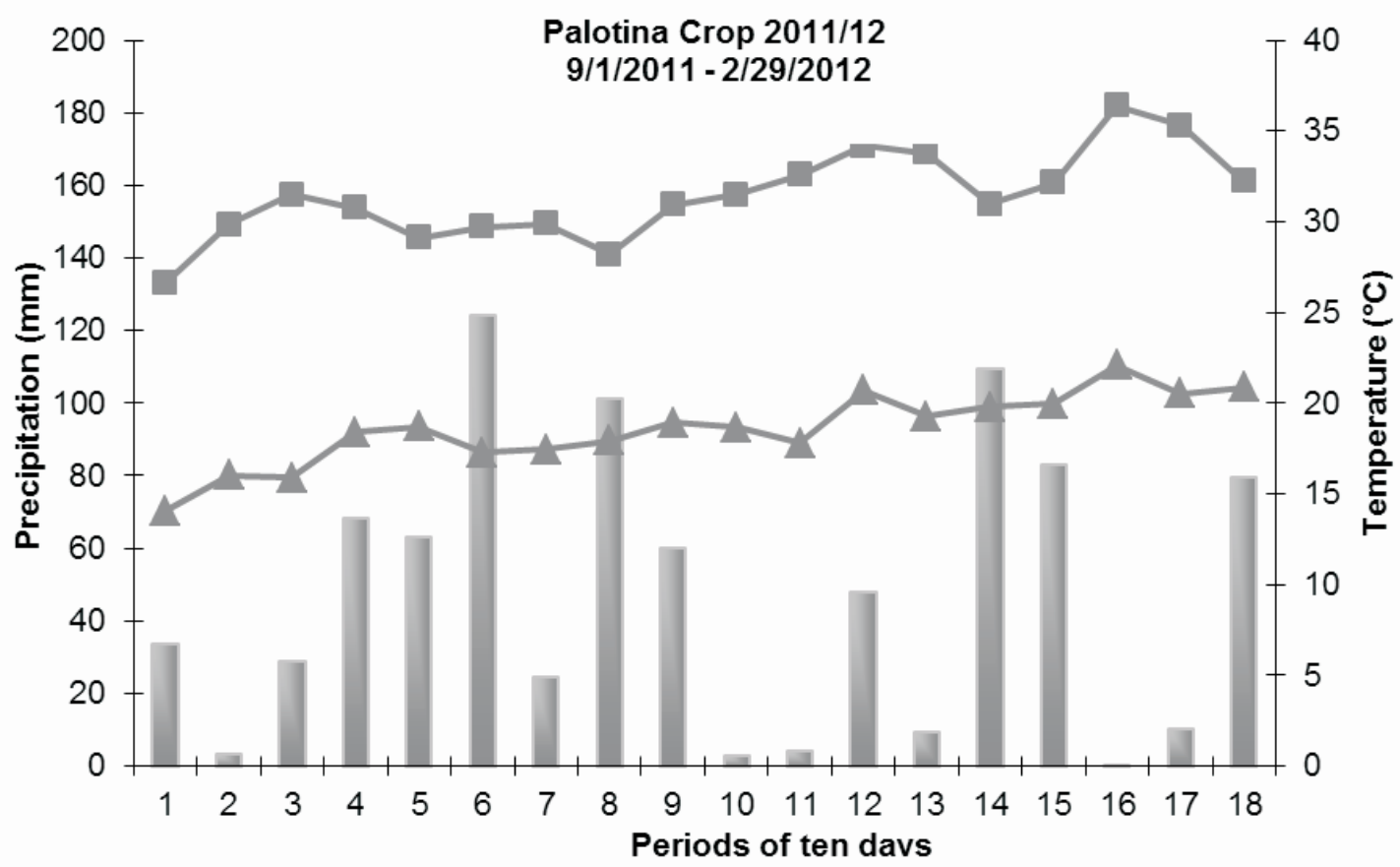

$\longrightarrow$ Precipitation $\rightarrow$ Minimum temperature $\rightarrow-$ Maximum temperature

Source: SIMEPAR.

Figure 1 - Precipitation and average (minimum and maximum) temperatures for the period related to the soybean culture in the city of Palotina in the 2011/2012 crop.

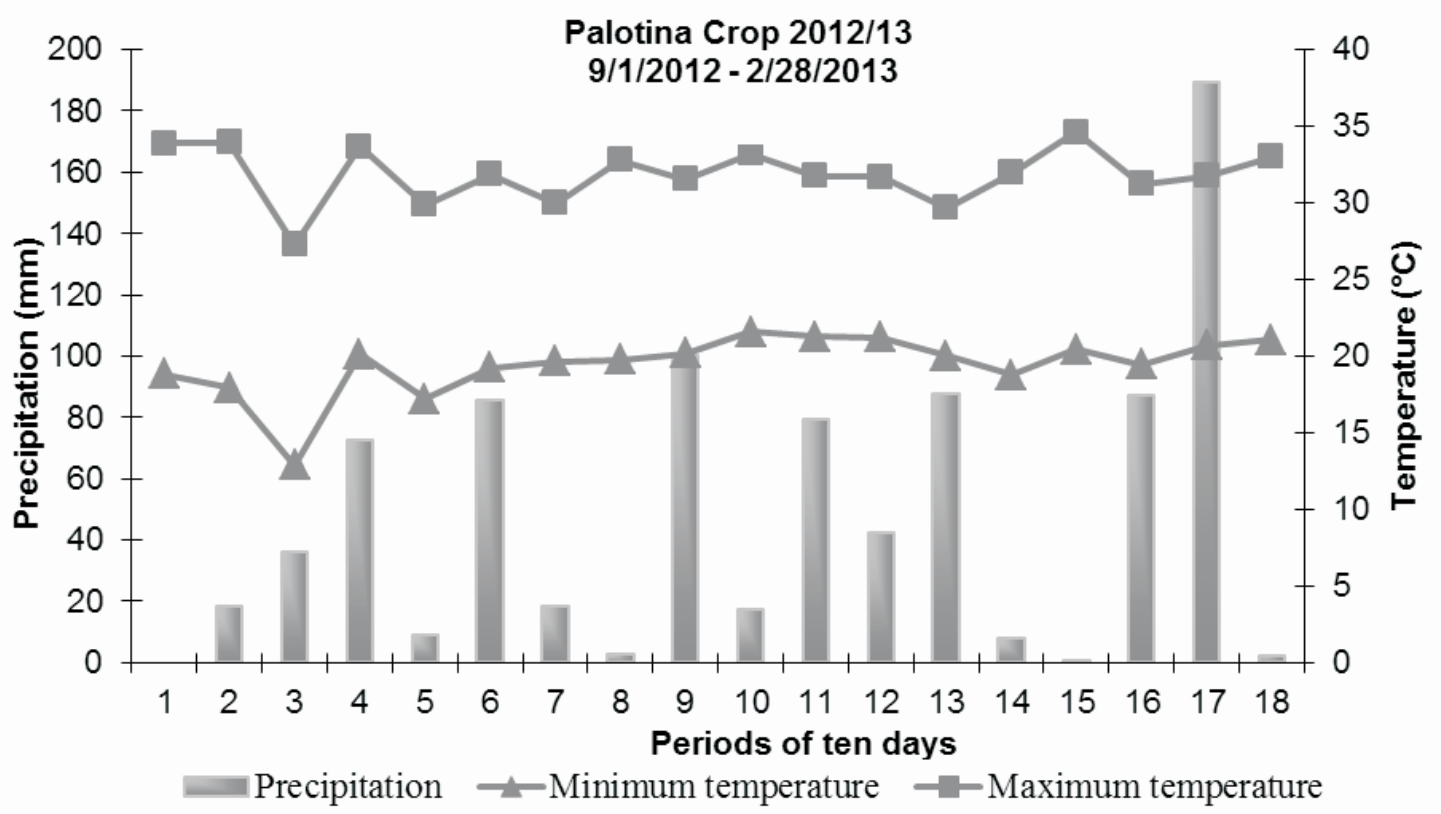

Source: SIMEPAR.

Figure 2 - Precipitation and average (minimum and maximum) temperatures for the period related to the soybean culture in the city of Palotina in the 2012/2013 crop. 
following criteria were adopted: biological explanation, significant regression, non significant regression deviation, coefficient of determination and analysis of residues.

\section{RESULTS AND DISCUSSION}

From the assessments performed and the statistical analysis of data for the 2011/12 crop, with respect to the variable height of plants (Table 1), difference was noted among the formulations only at the dose of $2,160 \mathrm{~g}$ e.a. ha- ${ }^{-1}$, but in the other assessed variables (number of pods per plant, yield and weight of 100 grains), no differences were observed $(P<0.05)$ among the tested formulations. Thus, a pattern of behavior can not be established to determine the superiority of one formulation over the other, within each dose.

In this experiment no traces of phytotoxicity were computed because symptoms or any other significant visual effects of treatments applied on coloration and plant development were not observed.

All interactions unfolding allowed the identification of effects $(P<0.05)$ by means of regression analysis for the variables plant height (Figure 3) and yield (Figure 4), and it was possible to adjust a decreasing linear model with increasing doses of glyphosate.

In regressions achieved for the two variables, the formulation containing the potassium salt $(Z)$ was significant (Figures 3 and 4). Yield decreased significantly with

Table 1 - Height of RR soybeans, submitted to the application of two formulations and five doses of glyphosate. Crop 2011/12, Palotina - PR

\begin{tabular}{|c|c|c|c|}
\hline \multirow{2}{*}{$\begin{array}{c}\text { Dose } \\
\left(\mathrm{g} \mathrm{e.a.} \text { ha }^{-1}\right)\end{array}$} & \multicolumn{2}{|c|}{ Height (cm) } & \multirow{2}{*}{ Average } \\
\cline { 2 - 3 } & $\begin{array}{c}\text { Isopropylamine } \\
\text { salt (R) }\end{array}$ & $\begin{array}{c}\text { Potassium } \\
\text { salt (Z) }\end{array}$ & \\
\hline 0 & $91.19 \mathrm{~A}$ & $89.31 \mathrm{~A}$ & 90.25 \\
\hline 720 & $87.19 \mathrm{~A}$ & $87.50 \mathrm{~A}$ & 87.34 \\
\hline 1440 & $89.88 \mathrm{~A}$ & $89.31 \mathrm{~A}$ & 89.59 \\
\hline 2160 & $92.63 \mathrm{~A}$ & $85.38 \mathrm{~B}$ & 89.00 \\
\hline 2880 & $84.88 \mathrm{~A}$ & $83.44 \mathrm{~A}$ & 84.16 \\
\hline Average & 89.15 & 86.99 & 88.07 \\
\hline CV $(\%)$ & 4.09 & & \\
\hline
\end{tabular}

Same letters in the line between the formulations ( $\mathrm{R}$ and $\mathrm{Z}$ ), within each dose, do not differ significantly $(P<0.05)$, by the $\mathrm{F}$ test.

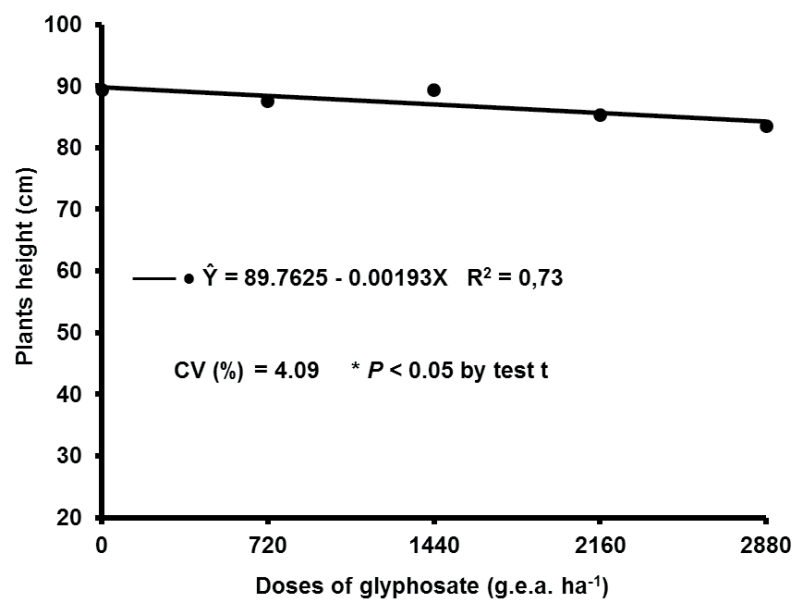

Figure 3 - Behavior of plant height due to doses of glyphosate in formulation $\mathrm{Z}$ (potassium salt). Crop 2011/2012, Palotina - PR.

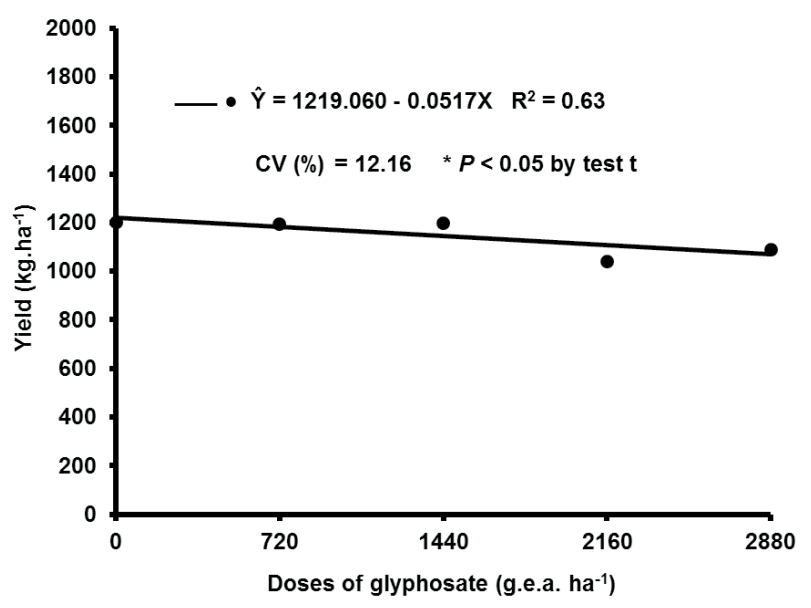

Figure 4 - Behavior of yield due to doses of glyphosate in formulation Z (potassium salt). Crop 2011/2012, Palotina - PR.

increasing doses of glyphosate (Figure 4), being recorded a decrease of $0.0517 \mathrm{~kg}$ of grains (51.7 grams) at every g e.a. ha-1 of glyphosate. The height was affected even in late application because the cultivar has an indeterminate growth habit, i.e., even the culture being in the reproductive stage, it still presents a significant rate of increase for a specified period after the onset of flowering.

For the experiment carried out in the 2011/12 crop, yields were low due to adverse conditions faced by the culture, in which mainly the water deficit between the $\mathrm{R} 2$ and R5 stages of development has severely affected 
the development of the culture. When a comparison between Figures 1 and 2 is done, it is possible to see the environmental difference between the two crops.

As this stress occurred during the reproductive phase, the plant suffered significantly with respect to productive traits, increasing the abortion of the flowers, and also by the fact that during this period the plant has its relationship source-drain changed; thus the grain filling (R5), which is considered one of the most critical stages of soybean development, was affected (Bergamin et al., 1999; Farias et al., 2007). With this, the agronomic performance of the culture was affected: in this first crop (2011/12), the average yield of the experimental area and the average mass of 100 grains were respectively $1153.57 \mathrm{~kg} \mathrm{ha}^{-1}$ and $8.16 \mathrm{~g}$; as for the second crop (2012/13), the average yield of the experimental area and the average weight of 100 grains were, respectively, $3473.21 \mathrm{~kg} \mathrm{ha}^{-1}$ and $17.61 \mathrm{~g}$, and this second crop is according to the historical averages in the region.

With regard to the results found in the 2012/13 crop, the behavior of the formulations was repeated for the variables related to the agronomic performance of the crop, because differences were not found between the two formulations, in doses $(P<0.05)$, for variables: height, number of pods per plant, weight of 100 grains and yield.

For the data regarding the assessments of phytotoxicity, it was necessary to use the option of transformation $(\mathrm{X}+1)^{0,5}$. However, with this data set, even with differences $(P<0.05)$ between the formulations, in the assessments of 7 and 14 DAA (Table 2) it is not possible to trace a clear pattern of behavior. At 28 DAA, it was no longer possible to observe visual phytotoxicity effects in the culture.

The same principle of effect found in the first harvest was noticed in the second crop, in which the variable height was affected again (Figure 5), because, as mentioned, the cultivar has an indeterminate growth habit; however, this decrease in crop height was detected for the average of the two formulations ( $\mathrm{R}$ and $\mathrm{Z}$ ). The differential point was that in the second crop phytotoxicity was observed in the culture, and it is possible to adjust an increasing linear model, with rising rates of glyphosate, for all developments performed (Figure 6).

Probably due to the combination of drought stress added to xenobiotic stress (glyphosate or AMPA), the yield variable was most affected in the first crop. As in the second crop soybeans developed in a more favorable climate, the physiological effects of glyphosate were shown again, but without compromising yield; however, they possibly affected the photosynthetic apparatus (Zobiole et al., 2010b,c), as in the decrease of height, demonstrating phytotoxicity in all developments.

Table 2 - Phytotoxicity at 7, 14 and 21 days after the application of two formulations and five doses of glyphosate in RR soybeans. Crop 2012/2013, Palotina - PR

\begin{tabular}{|c|c|c|c|}
\hline \multirow{2}{*}{$\begin{array}{c}\text { Dose } \\
\left(\mathrm{g} \mathrm{e} \cdot \mathrm{a} \cdot \mathrm{ha}^{-1}\right)\end{array}$} & \multicolumn{2}{|c|}{$\begin{array}{c}\text { Isopropylamine salt }(\mathrm{R}) \\
\text { Potassium salt }(\mathrm{Z})\end{array}$} & \multirow[t]{2}{*}{ Average } \\
\hline & \multicolumn{2}{|c|}{ Phytotoxicity 7 DAA (\%) } & \\
\hline 0 & $0.00 \mathrm{~A}$ & $0.00 \mathrm{~A}$ & 0.00 \\
\hline 720 & $0.00 \mathrm{~A}$ & $0.00 \mathrm{~A}$ & 0.00 \\
\hline 1440 & $4.75 \mathrm{~A}$ & $4.75 \mathrm{~A}$ & 4.75 \\
\hline 2160 & $6.75 \mathrm{~A}$ & $12.50 \mathrm{~B}$ & 9.63 \\
\hline 2880 & $16.25 \mathrm{~A}$ & $16.25 \mathrm{~A}$ & 16.25 \\
\hline Average & 5.55 & 6.70 & 6.13 \\
\hline \multirow[t]{2}{*}{$\mathrm{CV}(\%)$} & 11.86 & & \\
\hline & \multicolumn{2}{|c|}{ Phytotoxicity 14 DAA (\%) } & \\
\hline 0 & $0.00 \mathrm{~A}$ & $0.00 \mathrm{~A}$ & 0.00 \\
\hline 720 & $0.00 \mathrm{~A}$ & $0.00 \mathrm{~A}$ & 0.00 \\
\hline 1440 & $6.75 \mathrm{~A}$ & $6.75 \mathrm{~A}$ & 6.75 \\
\hline 2160 & $9.25 \mathrm{~A}$ & $13.75 \mathrm{~B}$ & 11.50 \\
\hline 2880 & $17.50 \mathrm{~A}$ & $17.50 \mathrm{~A}$ & 17.50 \\
\hline Average & 6.70 & 7.60 & 7.15 \\
\hline $\mathrm{CV}(\%)$ & 13.44 & & \\
\hline \multicolumn{4}{|c|}{ Phytotoxicity 21 DAA (\%) } \\
\hline 0 & $0.00 \mathrm{~A}$ & $0.00 \mathrm{~A}$ & 0.00 \\
\hline 720 & $0.00 \mathrm{~A}$ & $0.00 \mathrm{~A}$ & 0.00 \\
\hline 1440 & $1.25 \mathrm{~A}$ & $1.25 \mathrm{~A}$ & 1.25 \\
\hline 2160 & $2.50 \mathrm{~A}$ & $3.75 \mathrm{~A}$ & 3.12 \\
\hline 2880 & $7.50 \mathrm{~A}$ & $8.00 \mathrm{~A}$ & 7.75 \\
\hline Average & 2.25 & 2.60 & 2.43 \\
\hline CV $(\%)$ & 30.07 & & \\
\hline
\end{tabular}

Same letters in the line between the formulations (isopropylamine salt (R) and potassium salt $(\mathrm{Z})$ ), within each dose, do not differ significantly $(P<0.05)$, by the $\mathrm{F}$ test. 


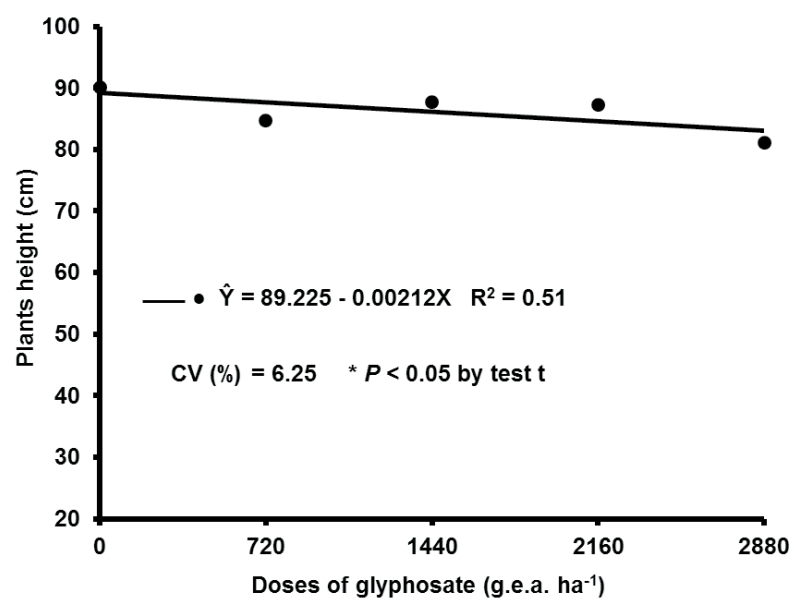

Figure 5 - Behavior of plant height due to doses of glyphosate. Crop 2012/2013, Palotina - PR.

Variations in behavior of culture between the two crops are mainly explained by the large difference between the two growing crops, in which environmental conditions were different, confirming Zablotowicz \& Reddy (2004), who point out that the physiological responses to glyphosate may vary according to environmental conditions and other factors.

Regarding phytotoxicity detected in the 2012/13 crop, the fact that environmental conditions for this location and year allowed visual detection of these symptoms deserves great attention, which had been dormant in the experiment conducted in the previous crop. This undesirable symptom in RR soybeans may be related to accumulation of AMPA, which is the first phytotoxic metabolite of glyphosate, (Reddy et al., 2004) and in conditions of low solar radiation could present boosted phytotoxicity.

Even taking into account that the formulations used have different salts in their composition, which, along with the surfactants present, provide differentiated penetration, absorption and translocation (Santos et al., 2007), the end effects observed in the culture, in both experiments, before the assessments conducted, were similar.

The effects became clearer in the factor doses, in which, for the variable yield in the first crop, phytotoxicity in the the second crop and height in both crops, potential deleterious
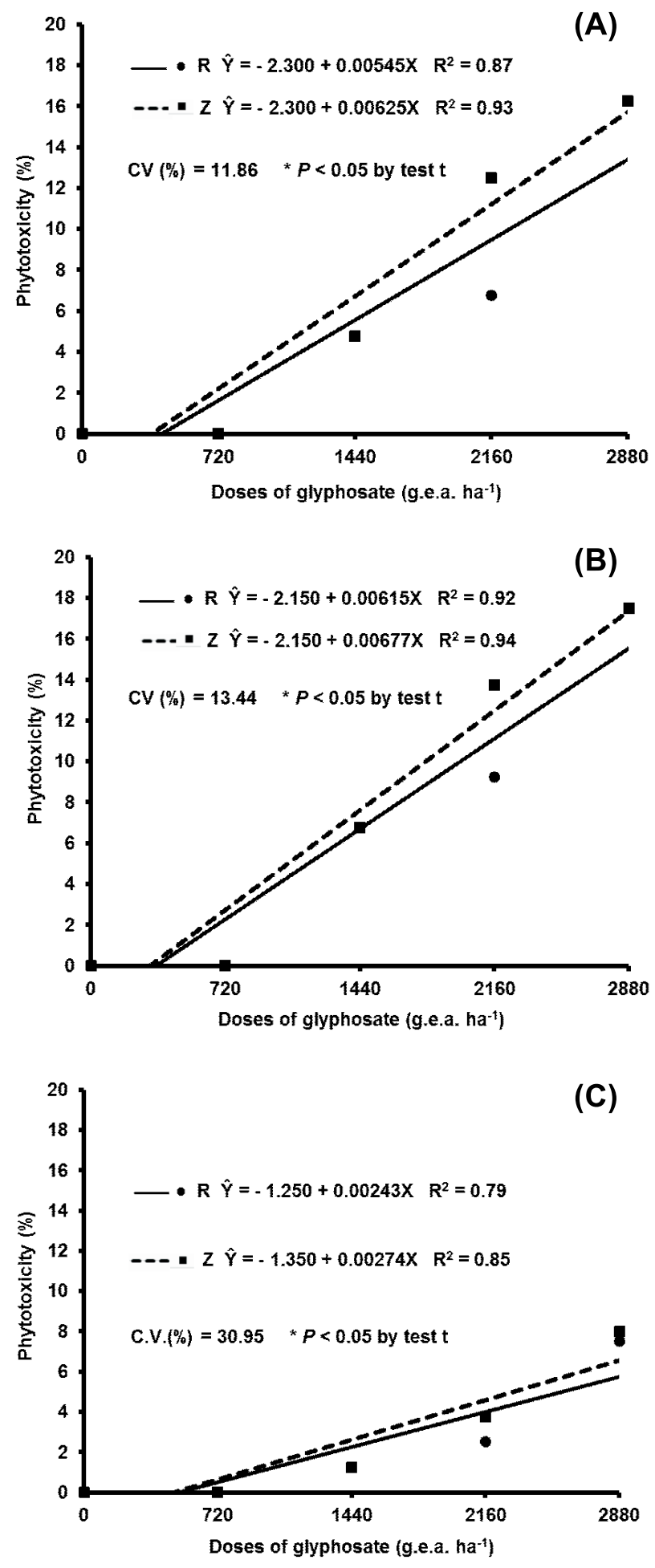

Figure 6 - Phytotoxicity of the plants, at 7 (A) 14 (B) and 21 (C) days after application, due to the doses of glyphosate, in formulations R (straight continuous - isopropylamine salt) and Z (straight dashed - potassium salt). Crop 2012/ 2013, Palotina - PR. 
effects were identified in these traits of agronomic interest, from increasing doses of glyphosate applied. These results are directly related to those discussed by several authors, probably because they are connected or arise from potential injury, or even from the harmful effects of glyphosate and its metabolites, as found in the literature (Reddy et al., 2004; Zablotowicz \& Reddy, 2004; Santos et al., 2007; Zablotowicz \& Reddy, 2007; Zobiole et al., 2010a,b,c; Albrecht, et al., 2011a,b; Albrecht et al., 2012a,b; Cavalieri et al., 2012).

From the results presented and discussed, it is understood that the application of glyphosate can linearly decrease the agronomic performance of RR soybeans when applied at the R1 stage. However, further studies are needed using different genotypes in different sowing dates in different regions, so that it is possible to consolidate a technicalscientific position on the subject and thus decrease the likely deleterious effects of glyphosate on the culture of RR soy, fostering a more secure and sustainable use of this important technology.

\section{ACKNOWLEDGMENT}

To CAPES (Coordination of Improvement of Higher Education) and, mainly, to FAPESP (Foundation to Support Research of the Brazilian state of São Paulo), for the support to the researchers. To farmer Alfredo Albrecht, for the fundamental help when conducting field experiments.

\section{LITERATURE CITED}

ALBRECHT, L. P.; ÁVILA, M. R. Manejo de glyphosate em soja RR e a qualidade das sementes. Inf. Abrates, v. 20, n. 2, p. 45-54, 2010.

ALBRECHT, L. P. et al. Qualidade fisiológica das sementes de soja RR em resposta ao uso de diferentes tratamentos contendo glyphosate em aplicação sequencial. Biosc. J., v. 27, n. 2, p. 211-220, 2011a.

ALBRECHT, L. P. et al. Desempenho da soja roundup ready sob aplicação de glyphosate em diferentes estádios. Planta Daninha, v. 29, n. 3, p. 558-590, 2011 b.
ALBRECHT, L. P. et al. Glyphosate e associações em pós-emergência no desempenho agronômico e na qualidade das sementes de soja RR. Planta Daninha, v. 30, n. 1, p. 139-146, 2012a.

ALBRECHT, L. P. et al. RR Soybean seed quality after application of glyphosate in different stages of development. R. Bras. Sementes, v. 34, n. 3, p. 373-381, $2012 b$.

ALBRECHT, L. P. et al. Soja RR e o Glyphosate. In: ALBRECHT, L.P.; MISSIO, R. F. Manejo de cultivos transgênicos. Curitiba: Universidade Federal do Paraná, 2013.p. 25-45.

BERGAMIN, M. et al. Ecofisiologia da soja. In: CASTRO, P. R. C.; KLUGE, R. A. (Org.). Ecofisiologia de cultivos anuais: trigo, milho, soja, arroz e mandioca. São Paulo: Nobel, 1999. p. 73-90.

CAVALIERI, S. D. et al. Acúmulo de nutrientes e matéria seca na parte aérea de dois cultivares de soja RR sob efeito de formulações de glyphosate. Planta Daninha, v. 30, n. 2, p. 349-358, 2012.

CÉLERES. Relatório biotecnologia. Uberlândia: 2012. Disponível em: <http://celeres.com.br/wordpress/wpcontent/uploads/2012/12/RelBiotecBrasil_1202_ por.pdf>. Acesso em: 17 fev. 2013.

COCAMAR. Jornal de serviços: notícias on line. 2012. Disponível em: $<$ http://www.jornalcocamar.com.br/ noticias. asp ? $i d=$ noticias $\& c=270 \& \mathrm{e}=33 \& \mathrm{n}=96>$. Acesso em: 27 fev. 2012.

CONAB. Estudos de prospecção de mercado: safra 2012/ 2013. Brasília, 2012a. 148 p. Disponível em $<$ http:// www.conab.gov.br/OlalaCMS/uploads/arquivos/ 12_09_11_16_41_03_prospeccao_12_13.pdf $>$. Acesso em: 10 out. 2013 .

\section{EMPRESA BRASILEIRA DE PESQUISA} AGROPECUÁRIA-EMBRAPA. Tecnologias de produção de soja: região central do Brasil: 2012 e 2013. Londrina: Embrapa Soja; Embrapa Cerrados; Embrapa Agropecuária Oeste, 2011.261 p. (Sistemas de Produção, 15).

FARIAS, J. R. B. et al. Ecofisiologia da soja. Londrina: Embrapa, 2007. 9 p. (Circular Técnica, 48).

FEHR, W. R. et al. Stage of development description for soybean, Glycine $\max$ (L.) Merrill. Crop Sci., v. 11, n. 6, p. 929-931, 1971. 
MONSANTO. Produtos: herbicidas. 2012. Disponível em: $<\mathrm{http}: / /$ www.monsanto.com.br/produtos/herbicidas/ herbicidas.asp>. Acesso em: 22 nov. 2012.

PIMENTEL-GOMES, F.; GARCIA, C. H. Estatística aplicada a experimentos agronômicos e florestais: exposição com exemplos e orientações para uso de aplicativos. Piracicaba: FEALQ, 2002.309 p.

REDDY, K. N. et al. Aminomethylphosphonic acid, a metabolite of glyphosate, causes injury in glyphosatetreated, glyphosate-resistant soybean. J. Agric. Food Chem., v. 52, p. 5139-5143, 2004.

SANTOS, J. B. et al. Efeito de formulações na absorção e translocação do glyphosate em soja transgênica.

Planta Daninha, v. 25, n. 2, p. 381-388, 2007.

SOCIEDADE BRASILEIRA DE PESQUISA DO SOLOSBCPD. Procedimentos para instalação, avaliação e analise de experimentos com herbicidas. Londrina: $1995.42 \mathrm{p}$.

VELINI, E. D. et al. Glyphosate. Botucatu: FEPAF, 2009. $493 \mathrm{p}$.
ZABLOTOWICZ, R. M.; REDDY, K. N. Impact of glyphosate on the Bradyrhizobium japonicum symbiosis with glyphosate-resistant transgenic soybean: a minireview. J. Environ. Quality, v. 33, n. 3, p. 825-831, 2004.

ZABLOTOWICZ, R.M.; REDDY, K.N. Nitrogenase activity, nitrogen content, and yield responses to glyphosate in glyphosate-resistant soybean. Crop Protection, Guildford, v. 26, n. 1, p. 370-376, 2007.

ZOBIOLE, L. H. S. et al. Effect of glyphosate on symbiotic $\mathrm{N} 2$ fixation and nickel concentration in glyphosate-resistant soybeans. Appl. Soil Ecol., v. 44, n. 2,p. 176-180,2010a.

ZOBIOLE, L. H. S. et al. Water use efficiency and photosynthesis of glyphosate-resistant soybean as affected by glyphosate. Pestic. Biochem. Physiol., v. 97, n. 3, p. 182-193, 2010 b.

ZOBIOLE, L. H. S. et al. Glyphosate affects lignin content and amino acid production in glyphosateresistant soybean. Acta Physiol. Plant., v. 32, n. 5, p. $831-837,2010$ c. 